\title{
Atmospheric changes caused by galactic cosmic rays over the period 1960-2010
}

\author{
Charles H. Jackman ${ }^{1}$, Daniel R. Marsh ${ }^{2}$, Douglas E. Kinnison ${ }^{2}$, Christopher J. Mertens ${ }^{3}$, and Eric L. Fleming ${ }^{1,4}$ \\ ${ }^{1}$ NASA Goddard Space Flight Center, Greenbelt, MD, USA \\ ${ }^{2}$ National Center for Atmospheric Research, Boulder, CO, USA \\ ${ }^{3}$ NASA Langley Research Center, Hampton, VA, USA \\ ${ }^{4}$ Science Systems and Applications Inc., Lanham, MD, USA \\ Correspondence to: Charles H. Jackman (charles.h.jackman@ nasa.gov)
}

Received: 28 October 2015 - Published in Atmos. Chem. Phys. Discuss.: 2 December 2015

Revised: 12 April 2016 - Accepted: 26 April 2016 - Published: 13 May 2016

\begin{abstract}
The Specified Dynamics version of the Whole Atmosphere Community Climate Model (SD-WACCM) and the Goddard Space Flight Center two-dimensional (GSFC 2-D) models are used to investigate the effect of galactic cosmic rays (GCRs) on the atmosphere over the 1960-2010 time period. The Nowcast of Atmospheric Ionizing Radiation for Aviation Safety (NAIRAS) computation of the GCRcaused ionization rates are used in these simulations. GCRcaused maximum $\mathrm{NO}_{x}$ increases of $4-15 \%$ are computed in the Southern polar troposphere with associated ozone increases of $1-2 \% . \mathrm{NO}_{x}$ increases of $\sim 1-6 \%$ are calculated for the lower stratosphere with associated ozone decreases of $0.2-1 \%$. The primary impact of GCRs on ozone was due to their production of $\mathrm{NO}_{x}$. The impact of GCRs varies with the atmospheric chlorine loading, sulfate aerosol loading, and solar cycle variation. Because of the interference between the $\mathrm{NO}_{x}$ and $\mathrm{ClO}_{x}$ ozone loss cycles (e.g., the $\mathrm{ClO}$ $+\mathrm{NO}_{2}+\mathrm{M} \rightarrow \mathrm{ClONO}_{2}+\mathrm{M}$ reaction) and the change in the importance of $\mathrm{ClO}_{x}$ in the ozone budget, GCRs cause larger atmospheric impacts with less chlorine loading. GCRs also cause larger atmospheric impacts with less sulfate aerosol loading and for years closer to solar minimum. GCR-caused decreases of annual average global total ozone (AAGTO) were computed to be $0.2 \%$ or less with GCR-caused column ozone increases between 1000 and $100 \mathrm{hPa}$ of $0.08 \%$ or less and GCR-caused column ozone decreases between 100 and $1 \mathrm{hPa}$ of $0.23 \%$ or less. Although these computed ozone impacts are small, GCRs provide a natural influence on ozone and need to be quantified over long time periods. This result serves as a lower limit because of the use of the
\end{abstract}

ionization model NAIRAS/HZETRN which underestimates the ion production by neglecting electromagnetic and muon branches of the cosmic ray induced cascade. This will be corrected in future works.

\section{Introduction}

Galactic cosmic rays (GCRs) from outside the solar system are comprised of highly energetic charged particles and are believed to be the result of supernova events and other high-energy astrophysical processes. GCRs contain a wide range of energetic particles, which are also influenced by the Earth's magnetosphere. High-energy GCRs not only penetrate further into the atmosphere, but can also cause atmospheric effects outside the polar cap regions. The flux of GCRs is larger during solar minimum, when the reduced solar magnetic field less effectively shields the solar system from the particles.

The influence of GCRs on the middle atmosphere has been studied since the 1970s (e.g., Warneck, 1972; Ruderman and Chamberlain, 1975; Nicolet, 1975; Jackman et al., 1980, 1987, 1996; Thorne, 1980; Garcia et al., 1984; Legrand et al., 1989; Jackman, 1991, 1993; Müller and Crutzen, 1993; Vitt and Jackman, 1996; Krivolutsky et al., 1999, 2001, 2002; Vitt et al., 2000; Semeniuk et al., 2011; Calisto et al., 2011). These previous studies made use of GCR-produced ionization rates (GPIR) in computing atmospheric chemistry impacts. The GPIR were deduced primarily in a couple of different methodologies. 
For example, Nicolet (1975) made use of balloon soundings and ionization chambers to compute the GPIR. Several of the other earlier studies roughly followed the Nicolet (1975) methodology for inclusion of GPIR in atmospheric analyses. A more recent study by Calisto et al. (2011) primarily relied on the computations of the Cosmic Ray induced Cascade: Application for Cosmic Ray Induced Ionization (CRAC : CRII) of Usoskin et al. (2010) to deduce the GPIR. Another method of computing GPIR has been developed by the Nowcast of Atmospheric Ionizing Radiation for Aviation Safety (NAIRAS) team at NASA Langley Research Center (see Mertens et al., 2013). The NAIRAS-deduced GPIR has been computed over the years 1960-2010. The solar cycle shows substantial variation over this 51-year time period, which is reflected in the GPIR.

GCRs also affect the atmosphere through the production of the important constituent families of $\mathrm{NO}_{x}\left(\mathrm{~N}, \mathrm{NO}, \mathrm{NO}_{2}\right)$ and $\mathrm{HO}_{x}\left(\mathrm{H}, \mathrm{OH}, \mathrm{HO}_{2}\right)$ either directly or through a photochemical sequence. The NAIRAS-deduced GPIR and subsequent $\mathrm{NO}_{x}$ and $\mathrm{HO}_{x}$ production can be used in atmospheric models to predict impact on constituents over the 1960-2010 period. We use two models, the Specified Dynamics - Whole Atmosphere Community Climate Model (SD-WACCM) and the Goddard Space Flight Center (GSFC) two-dimensional (2-D) model, to study the influence of GCRs on the atmosphere over these 51 years. SD-WACCM is used for detailed studies of the impact of GCRs on minor atmospheric constituents. The GSFC 2-D model helps in the quantification of the changing GCR influence between 1960 and 2010 as the chlorine-loading, sulfate aerosol amount, solar cycle, and dynamics vary over this time period. The fast computational speed of the GSFC 2-D model (compared with SD-WACCM) allows a number of simulations to investigate the sensitivity of the GCR influence in different changing background atmospheres.

This paper is divided into six primary sections, including the Introduction. The NAIRAS GCR ionization rate computation is discussed in Sect. 2 and the GCR-induced production of $\mathrm{HO}_{x}$ and $\mathrm{NO}_{x}$ are discussed in Sect. 3. A description of the two models (SD-WACCM and GSFC 2-D) used in this work is given in Sect. 4. Model results (both SD-WACCM and GSFC 2-D) for several GCR-caused atmospheric constituent changes are shown in Sect. 5. The conclusions are presented in Sect. 6.

\section{NAIRAS GCR ionization rate}

The Nowcast of Atmospheric Ionizing Radiation for Aviation Safety (NAIRAS) team at NASA Langley Research Center (see http://sol.spacenvironment.net/ nairas/) has developed and integrated a model to include GCRs into their ionizing radiation computation. The interplanetary magnetic field varies over a solar cycle and provides a modulation of the GCR spectral flux, which has been referred to as a solar modulation potential (e.g., Badhwar and O'Neill, 1996). For real-time application of the NAIRAS model, four real-time, high-latitude, ground-based neutron monitor count rate measurements are used to cross correlate with the solar modulation potential and provide the NAIRAS model's GCR spectral flux incident on the Earth for penetration into and through the atmosphere. NAIRAS is a physics-based model that maximizes the use of measurement input data (Mertens et al., 2013, and references therein).

In the NAIRAS model, GCRs travel from outside the heliosphere to 1 AU by the Badhwar and O'Neill (1992, 1994, 1996) and O'Neill (2010) NASA model, with the solar modulation potential determined from measurements of groundbased neutron monitor count rates. The GCR spectral flux at $1 \mathrm{AU}$ travel through the magnetosphere by means of a transmission factor determined by the vertical geomagnetic cutoff rigidity computed in the International Geomagnetic Reference Field model (Finlay et al., 2010). The vertical cutoff rigidities are determined by numerical solutions of charged particle trajectories in the IGRF field using the techniques advanced by Smart and Shea (1994, 2005). After transmission through the magnetosphere, the GCR spectral flux travels through the neutral atmosphere using the NASA HZETRN deterministic transport code (Mertens et al., 2012). The global distribution of atmospheric mass density is obtained from NCAR/NCEP Reanalysis 1 data at pressure levels larger than $10 \mathrm{hPa}$ (Kalnay et al., 1996) and the Naval Research Laboratory Mass Spectrometer and Incoherent Scatter model atmosphere data at pressure levels less than $10 \mathrm{hPa}$ (Picone et al., 2002).

The NAIRAS model has been used to compute the annual average GCR-produced ionization rates (GPIR) for the 1960-2010 time periods. For these time periods, measurements from the Thule and Izmiran neutron monitor stations were used to determine the solar modulation potential. GPIR in the NAIRAS model are computed by multiplying the dose rate in air by the atmospheric density, divided by $35 \mathrm{eV}$ per ion pair. The annual average GPIR from the NAIRAS model for 2 years, 2002 and 2009, are presented in Fig. 1. This shows the inverse relationship between GPIR and solar activity. Year 2002 is very close to solar maximum and shows a smaller GPIR with maximum ionization rates of nearly $15 \mathrm{~cm}^{-3} \mathrm{~s}^{-1}$, whereas year 2009 is very close to solar minimum with about a factor of two larger maximum ionization rate of $30 \mathrm{~cm}^{-3} \mathrm{~s}^{-1}$. The time-dependent variation in the GPIR at $90^{\circ} \mathrm{S}$ and $90^{\circ} \mathrm{N}$ is given in Fig. 2. Peaks in GPIR occur in 1965, 1977, 1987, 1997, and 2009, reflective of solar minimum conditions in those years. The north-south asymmetry in the GPIR is due to a systematic hemispherical asymmetry in the NCEP atmospheric density profiles.

The Mertens et al. (2013) GPIR are about a factor of two smaller than those presented in Usoskin et al. (2010), and the altitude of the maximum in the GPIR is lower in the NAIRAS results as well. A comparison of these two computations of GCR ion rates at $90^{\circ} \mathrm{N}$ is given in Fig. 3 for both solar mini- 


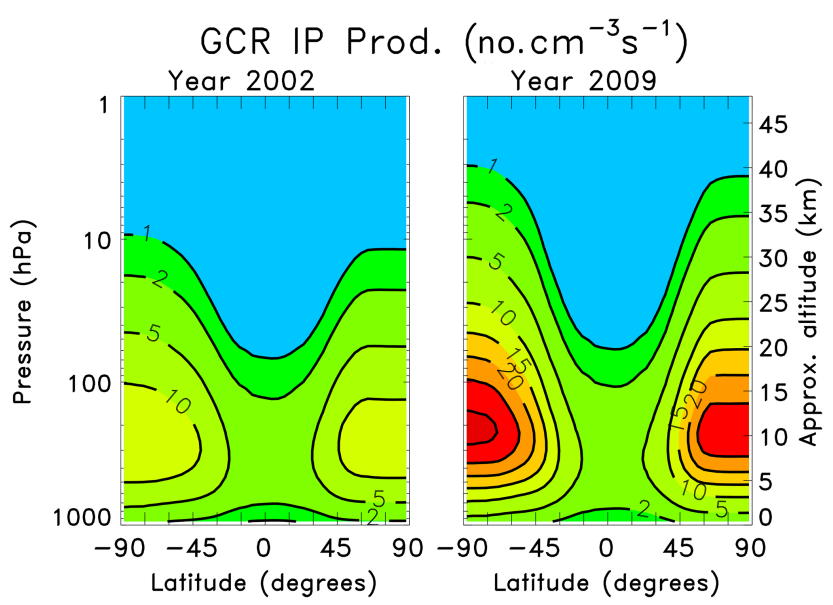

Figure 1. NAIRAS model computed GCR annual average ionization rates for years 2002 (left) and 2009 (right). Contour intervals are $1,2,5,10,15,20,25$, and $30\left(\# \mathrm{~cm}^{-3} \mathrm{~s}^{-1}\right)$.

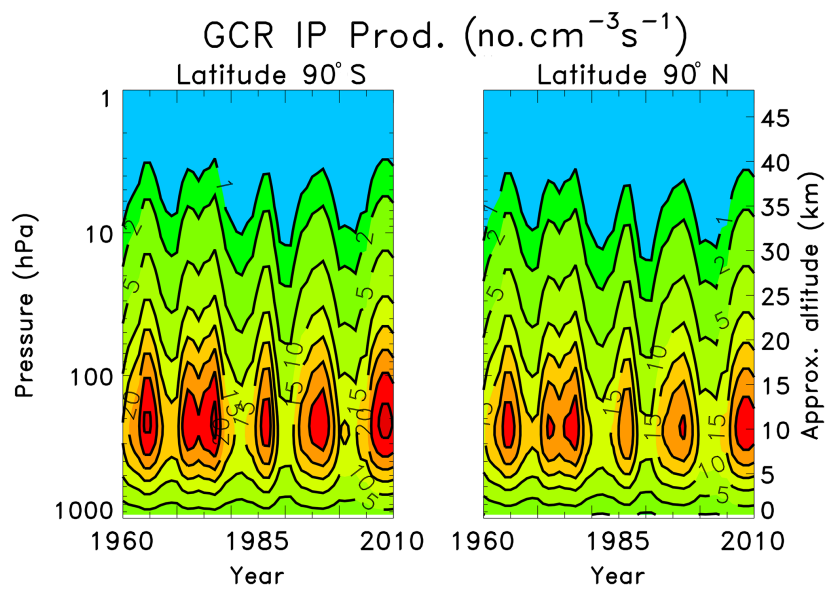

Figure 2. NAIRAS model computed galactic cosmic ray annual average ionization rates at $90^{\circ} \mathrm{S}$ (left) and $90^{\circ} \mathrm{N}$ (right) over the time period 1960-2010. Contour intervals are 1, 2, 5, 10, 15, 20, 25, and $30\left(\# \mathrm{~cm}^{-3} \mathrm{~s}^{-1}\right)$.

mum (1965) and solar maximum (1960) conditions. The underprediction of the NAIRAS GPIR and the lower altitude of its maximum is due to the lack of pion-initiated electromagnetic cascade processes in the HZETRN version 2010 currently implemented in the NAIRAS model (Mertens et al., 2013). This deficiency will soon be rectified when the 2015 version of HZETRN is integrated into the NAIRAS model (e.g., Norman et al., 2012, 2013; Slaba et al., 2013).

\section{$3 \mathrm{NO}_{x}\left(\mathrm{~N}, \mathrm{NO}, \mathrm{NO}_{2}\right)$ and $\mathrm{HO}_{x}\left(\mathrm{H}, \mathrm{OH}, \mathrm{HO}_{2}\right)$ production}

Besides ionization, GCRs also produce the important constituent families of $\mathrm{NO}_{x}\left(\mathrm{~N}, \mathrm{NO}, \mathrm{NO}_{2}\right)$ and $\mathrm{HO}_{x}(\mathrm{H}, \mathrm{OH}$, $\mathrm{HO}_{2}$ ) either directly or through a photochemical sequence.
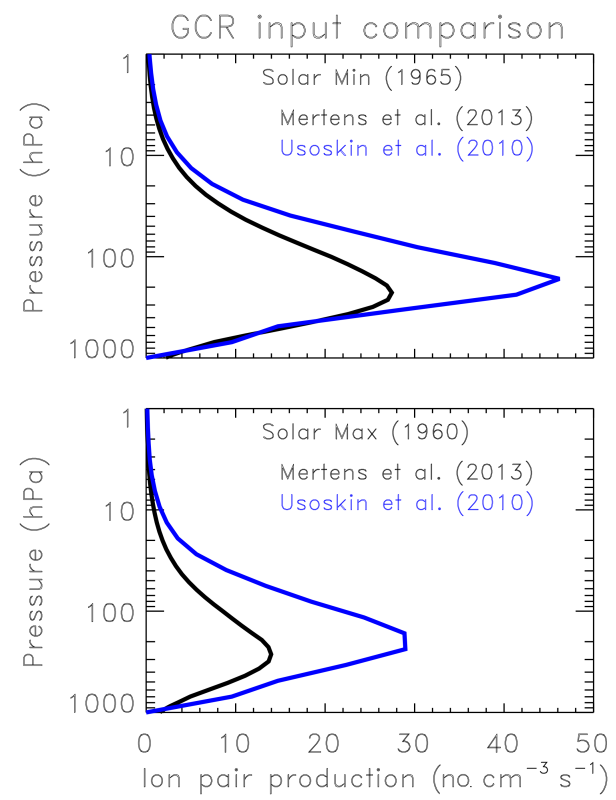

Figure 3. NAIRAS model computed galactic cosmic ray annual average ionization rates (Mertens et al., 2013) compared to those given in Usoskin et al. (2010) for solar minimum (1965, top plot) and solar maximum (1960, bottom plot).

$\mathrm{NO}_{x}$ is produced when the cosmic rays (primarily protons and their associated secondary electrons) dissociate $\mathrm{N}_{2}$ as they precipitate into the atmosphere. Here it is assumed that $1.25 \mathrm{~N}$ atoms are produced per ion pair and the proton impact of $\mathrm{N}$ atom production is divided between the ground state $\mathrm{N}\left({ }^{4} \mathrm{~S}\right)\left(45 \%\right.$ or 0.55 per ion pair) and excited state $\mathrm{N}\left({ }^{2} \mathrm{D}\right)$ ( $55 \%$ or 0.7 per ion pair) nitrogen atoms (Porter et al., 1976). GCRs also result in the production of $\mathrm{HO}_{x}$ through complex positive ion chemistry (Solomon et al., 1981). The charged particle-produced $\mathrm{HO}_{x}$ is a function of ion pair production and altitude and is included in model simulations using a lookup table from Jackman et al. (2005, Table 1), which is based on the work of Solomon et al. (1981). Each ion pair results in the production of about two $\mathrm{HO}_{x}$ constituents for the troposphere, stratosphere, and lower mesosphere and less than two $\mathrm{HO}_{x}$ constituents for the middle and upper mesosphere.

\section{Model predictions}

\subsection{Description of the Specified Dynamics - Whole Atmosphere Community Climate Model}

The latest version of the NCAR Community Earth System Model, version 1 (CESM1) Specified Dynamics - Whole Atmosphere Community Climate Model (SD-WACCM) was used to predict the impact of GCRs on the atmosphere. SDWACCM is a global model with 88 vertical levels from the surface to $4.5 \times 10^{-6} \mathrm{hPa}$ (approximately $140 \mathrm{~km}$ geometric 
Table 1. Description of model simulations.

\begin{tabular}{|c|c|c|c|c|}
\hline Simulation designation & Model & Time period (Years) & Include GCRs & Other information \\
\hline Base_SD-W & SD-WACCM & 2000-2009 & No & $\begin{array}{l}\text { Interannual MERRA Transport } \\
\text { No Sulfate Aerosol (SA) Variation } \\
\text { No Solar Cycle (SC) Photon Flux (PF) Var. }\end{array}$ \\
\hline$G C R \_S D-W$ & SD-WACCM & 2000-2009 & $\begin{array}{l}\text { Yes, Interannually } \\
\text { Varying }\end{array}$ & $\begin{array}{l}\text { Interannual MERRA Transport } \\
\text { No SA Var., No SC PF Var. }\end{array}$ \\
\hline A_Base_GSFC & GSFC 2-D & 1960-2010 & No & $\begin{array}{l}\text { Climatological Averaged Transport } \\
\text { No SA Var., No SC PF Var. }\end{array}$ \\
\hline B_Base_GSFC & GSFC 2-D & 1960-2010 & No & $\begin{array}{l}\text { Interannual Transport } \\
\text { No SA Var., No SC PF Var. }\end{array}$ \\
\hline C_Base_GSFC & GSFC 2-D & 1960-2010 & No & $\begin{array}{l}\text { Climatological Averaged Transport } \\
\text { SA Var., No SC PF Var. }\end{array}$ \\
\hline D_Base_GSFC & GSFC 2-D & 1960-2010 & No & $\begin{array}{l}\text { Climatological Averaged Transport } \\
\text { No SA Var., SC PF Var. }\end{array}$ \\
\hline E_Base_GSFC & GSFC 2-D & 1960-2010 & No & $\begin{array}{l}\text { Interannual Transport } \\
\text { SA Var., SC PF Var. }\end{array}$ \\
\hline$A 1 \_G C R \_G S F C$ & GSFC 2-D & 1960-2010 & $\begin{array}{l}\text { Yes, Mean of } \\
\text { Values }\end{array}$ & $\begin{array}{l}\text { Climatological Averaged Transport } \\
\text { No SA Var., No SC PF Var. }\end{array}$ \\
\hline$A 2 \_G C R \_G S F C$ & GSFC 2-D & 1960-2010 & $\begin{array}{l}\text { Yes, Interannually } \\
\text { Varying }\end{array}$ & $\begin{array}{l}\text { Climatological Averaged Transport } \\
\text { No SA Var., No SC PF Var. }\end{array}$ \\
\hline B1_GCR_GSFC & GSFC 2-D & 1960-2010 & $\begin{array}{l}\text { Yes, Mean of } \\
\text { Values }\end{array}$ & $\begin{array}{l}\text { Interannual Transport } \\
\text { No SA Var., No SC PF Var. }\end{array}$ \\
\hline$B 2 \_G C R \_G S F C$ & GSFC 2-D & 1960-2010 & $\begin{array}{l}\text { Yes, Interannually } \\
\text { Varying }\end{array}$ & $\begin{array}{l}\text { Interannual Transport } \\
\text { No SA Var., No SC PF Var. }\end{array}$ \\
\hline$C \_G C R \_G S F C$ & GSFC 2-D & 1960-2010 & $\begin{array}{l}\text { Yes, Mean of } \\
\text { Values }\end{array}$ & $\begin{array}{l}\text { Climatological Averaged Transport } \\
\text { SA Var., No SC PF Var. }\end{array}$ \\
\hline$D \_G C R \_G S F C$ & GSFC 2-D & 1960-2010 & $\begin{array}{l}\text { Yes, Mean of } \\
\text { Values }\end{array}$ & $\begin{array}{l}\text { Climatological Averaged Transport } \\
\text { No SA Var., SC PF Var. }\end{array}$ \\
\hline$E \_G C R \_G S F C$ & GSFC 2-D & 1960-2010 & $\begin{array}{l}\text { Yes, Interannually } \\
\text { Varying }\end{array}$ & $\begin{array}{l}\text { Interannual Transport } \\
\text { SA Var., SC PF Var. }\end{array}$ \\
\hline
\end{tabular}

height). SD-WACCM was most recently described in Wegner et al. (2013) and Solomon et al. (2015) and uses prescribed dynamical fields (e.g., see Lamarque et al., 2012) from the NASA Global Modeling and Assimilation Office Modern-Era Retrospective Analysis for Research and Applications (MERRA) (Rienecker et al., 2011). Temperature, zonal and meridional winds, and surface pressure are used to drive the physical parameterizations that control boundary layer exchanges, advective and convective transport, and the hydrological cycle. The SD-WACCM meteorological fields are relaxed toward the MERRA reanalysis fields using the approach described in Kunz et al. (2011).

The chemical module of SD-WACCM is based upon the 3-D chemical transport Model of Ozone and Related Tracers, Version 3 (MOZART) (Kinnison et al., 2007). It includes a detailed representation of the chemical and physical processes from the troposphere through the lower thermosphere. The species included within this mechanism are contained within the $\mathrm{O}_{x}, \mathrm{NO}_{x}, \mathrm{HO}_{x}, \mathrm{ClO}_{x}$, and $\mathrm{BrO}_{x}$ chemical families, along with $\mathrm{CH}_{4}$ and its degradation products. SD-WACCM also includes 17 primary nonmethane hydrocarbons and related oxygenated organic compounds (Em- mons et al., 2010). This mechanism contains 134 species, 420 chemical reactions, with 17 heterogeneous reactions on multiple aerosol types (i.e., sulfate, nitric acid trihydrate, and water-ice; Solomon et al., 2015). Reaction rates have been updated to JPL-2010 (Sander et al., 2011). Tropospheric $\mathrm{NO}_{x}$ production from lightning and aircraft is included as described in Lamarque et al. (2012).

For this work, the SPARC Chemistry Climate Model Initiative (CCMI), REFC1 scenario was used (see Eyring et al., 2013). This scenario included observed time-dependent evolution of greenhouse gases (GHGs); ozone depleting substances (ODSs); sea surface temperatures and sea ice concentrations (SSTs/SICs); stratospheric sulfate surface area densities (SADs); and 11-year solar cycle variability, which includes spectrally resolved solar irradiances.

\subsection{Description of the Goddard Space Flight Center Two-Dimensional Model}

The most recent version of the Goddard Space Flight Center (GSFC) two-dimensional (2-D) atmospheric model was used to predict the impact of GCRs on the atmosphere. This model was first discussed over 25 years ago (Douglass et al., 1989; 
Jackman et al., 1990) and has undergone extensive improvements over the years (e.g., Considine et al., 1994; Jackman et al., 1996; Fleming et al., 1999, 2007, 2011, 2015). The vertical range of the model, equally spaced in log pressure, is from the ground to approximately $92 \mathrm{~km}(0.0024 \mathrm{hPa})$ with about a $1 \mathrm{~km}$ grid spacing. The model has a $4^{\circ}$ latitude grid spacing.

The specified transport version of the model is used for this study. Here, the model transport fields are derived using daily average global winds and temperatures from the $\mathrm{Na}-$ tional Centers for Environmental Prediction-National Center for Atmospheric Research (NCEP-NCAR) reanalysis project for years 1960-1978 (Kalnay et al., 1996; Kistler et al., 2001) and the MERRA meteorological analyses for years 19792010. Thirty-day running averages of the residual circulation, eddy diffusion, zonal mean wind, and zonal mean temperature are computed using the methodology detailed in Fleming et al. (2007). For use in some of the simulations a climatological average was constructed of the transport over these years and applied it over the simulated periods. The averaged transport fields change daily, but repeat yearly.

The ground boundary conditions in the GSFC 2-D model for the ozone depleting substances are taken from WMO (2014) for years 1960-2010. The model uses a chemical solver described in Jackman et al. (2005) and Fleming et al. (2007, 2011). For these computations, the photochemical gas and heterogeneous reaction rates and photolysis cross sections have been updated to the Jet Propulsion Laboratory recommendations (Sander et al., 2011) with further updates based on SPARC (2013).

The model tropospheric chemistry scheme has also been updated to include the following species: $\mathrm{CH}_{3} \mathrm{OH}, \mathrm{C}_{2} \mathrm{H}_{6}$, $\mathrm{CH}_{3} \mathrm{CHO}, \mathrm{CH}_{3} \mathrm{CO}_{3}, \mathrm{CH}_{3} \mathrm{C}(\mathrm{O}) \mathrm{OOH}, \mathrm{CH}_{3} \mathrm{CO}_{3} \mathrm{NO}_{2}$ (peroxy acetyl nitrate, $\mathrm{PAN}$ ), $\mathrm{C}_{2} \mathrm{H}_{5} \mathrm{O}_{2}, \mathrm{C}_{2} \mathrm{H}_{5} \mathrm{OOH}, \mathrm{CH}_{3} \mathrm{COCH}_{3}$ (acetone), and $\mathrm{C}_{5} \mathrm{H}_{8}$ (isoprene). For this, the following quantities are specified using a 4-year average (2004-2007) of output from recent simulations of the Global Modeling Initiative's (GMI) combined stratosphere-troposphere chemistry and transport model (Strahan et al., 2007; Duncan et al., 2007; Strode et al., 2015): surface emissions of $\mathrm{CH}_{2} \mathrm{O}$, $\mathrm{CO}, \mathrm{NO}_{x}, \mathrm{C}_{2} \mathrm{H}_{6}$, and isoprene; surface mixing ratio boundary conditions for acetone, and tropospheric $\mathrm{NO}_{x}$ production from lightning and aircraft. The model tropospheric $\mathrm{OH}$ is specified from the monthly varying $\mathrm{OH}$ field documented in Spivakovsky et al. (2000). Surface dry deposition rates for $\mathrm{H}_{2} \mathrm{O}_{2}, \mathrm{CH}_{2} \mathrm{O}, \mathrm{CH}_{3} \mathrm{OOH}, \mathrm{HNO}_{3}, \mathrm{NO}_{2}, \mathrm{~N}_{2} \mathrm{O}_{5}, \mathrm{PAN}$, and $\mathrm{O}_{3}$, and tropospheric washout rates for $\mathrm{HO}_{2}, \mathrm{H}_{2} \mathrm{O}_{2}$, $\mathrm{CH}_{2} \mathrm{O}, \mathrm{CH}_{3} \mathrm{OOH}, \mathrm{HONO}, \mathrm{HNO}_{3}, \mathrm{HO}_{2} \mathrm{NO}_{2}, \mathrm{NO}_{2}, \mathrm{NO}_{3}$, and $\mathrm{N}_{2} \mathrm{O}_{5}$ are also specified from the GMI output. The resulting 2-D distributions of tropospheric $\mathrm{NO}_{x}$ and ozone (as well as $\mathrm{HNO}_{3}, \mathrm{CO}, \mathrm{C}_{2} \mathrm{H}_{6}$, and PAN) compare well with the GMI simulations and the ozone climatology compiled by McPeters et al. (2007). This allows the model to be used to simulate the GCR perturbations in the stratosphere and troposphere addressed in this study.

\subsection{Model simulations}

We conducted 14 model simulations with the two models, which are all briefly described in Table 1. SD-WACCM was used for two simulations, both over the period 2000-2010. One of the SD-WACCM simulations did not include GCRs (simulation Base_SD-W), whereas the other did (simulation $\left.G C R \_S D-W\right)$.

The GSFC 2-D model was used for 12 simulations, all over the 51-year period 1960-2010. The transport was specified for all simulations, either interannually varying with NCEP-NCAR data for years 1960-1978 and with MERRA data for years 1979-2010 or with a climatological average of those data over the 1960-2010 time period. Five of the simulations (labeled *_Base_GSFC) did not include GCRs and seven of the simulations (labeled *_GCR_GSFC) did include GCRs. Four simulations $\left(A 1 \_G C R \_G S F C, B 1 \_G C R \_G S F C, C \_G C R \_G S F C\right.$, and $D \_$ $G C R_{-} G S F C$ ) used a 51-year average of the GCR amount and three simulations (A2_GCR_GSFC, B2_GCR_GSFC, and $E_{-} G C R \_G S F C$ ) included the interannual variation of GCRs. These simulations investigated the impact of GCRs in a changing atmosphere of different chlorine-loading, sulfate aerosol amount, solar photon flux, and dynamics over this time period.

\section{Results}

SD-WACCM and GSFC 2-D model simulations were compared to delineate the GCR-caused changes under different atmospheric conditions. Model simulations were compared for the year 2009 (solar minimum, GCR maximum) to determine the GCR impact on several constituents in Sect. 5.1. The influence of GCRs over the solar cycle is also shown in Sect. 5.1 (comparing year 2009 to year 2002). Changing atmospheric conditions over the years 1960-2010 and their impact on the GCR atmospheric influence are shown in Sect. 5.2. In particular, GCR-caused global total ozone changes in the different regions of the atmosphere (1000 $100,100-1$, and $1000-1 \mathrm{hPa}$ ) are discussed in Sect. 5.2 as well as the global total ozone changes caused by GCRs with different imposed atmospheric conditions. Finally, the GCRcaused $\mathrm{NO}_{y}$ production is given in comparison to the $\mathrm{N}_{2} \mathrm{O}$ oxidation-caused $\mathrm{NO}_{y}$ production in Sect. 5.3.

\section{$5.1 \mathrm{NO}_{x}$, Ozone, $\mathrm{HO}_{x}$, and $\mathrm{HNO}_{3}$}

The GCR-caused $\mathrm{NO}_{x}\left(\mathrm{NO}+\mathrm{NO}_{2}\right)$ impact is shown in Fig. 4 (top) for SD-WACCM and in Fig. 5 (top) for the GSFC 2-D model. $\mathrm{NO}_{x}$ is mostly enhanced throughout the domain from 1000 to $1 \mathrm{hPa}$ with largest increases (>15\%) in the south polar troposphere. GCR-caused $\mathrm{NO}_{x}$ increases over $6 \%$ are computed in the north polar lower stratosphere. Although there are differences between the SD-WACCM and GSFC 2-D model computations shown here and those computed by 

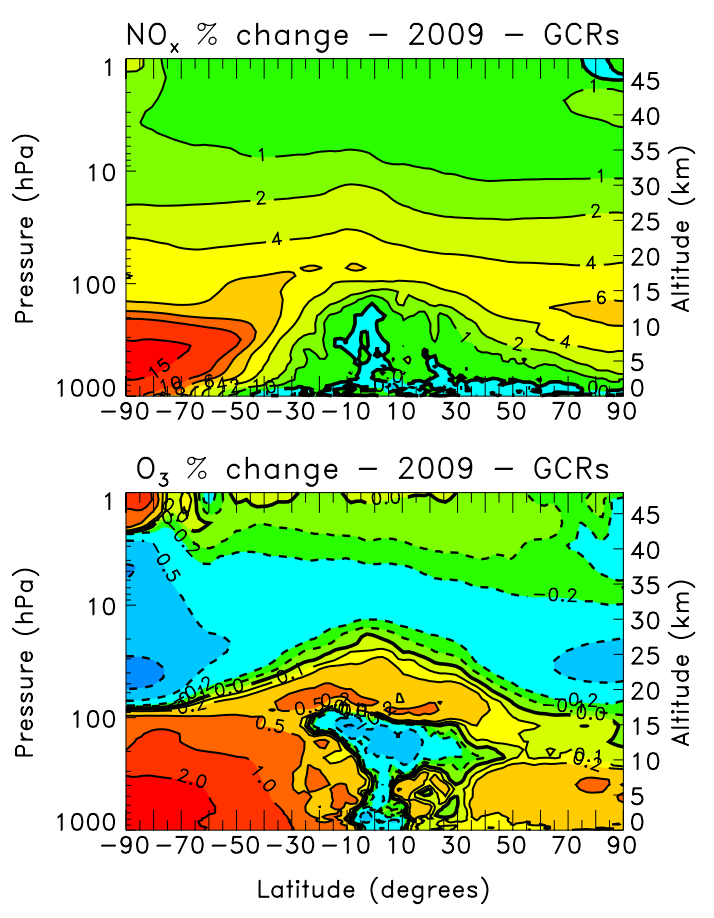

Figure 4. Annual average percentage change for year 2009 in zonal mean $\mathrm{NO}_{x}$ (top) and ozone (bottom) due to GCRs in the SDWACCM (simulation Base_SD_W compared to $G C R \_S D \_W$ ). The contour intervals for the $\mathrm{NO}_{x}$ changes are $0,1,2,4,6,8,10$, and $15 \%$. The contour intervals for the ozone changes are $-1,-0.5$, $-0.2,-0.1,0,0.1,0.2,0.5,1$, and $2 \%$.

Calisto et al. (2011), there are many similarities including the larger computed GCR-caused $\mathrm{NO}_{x}$ impact in the south polar tropospheric region compared with the north polar tropospheric region. The larger percentage change in the SH po$\operatorname{lar}\left(60-90^{\circ} \mathrm{S}\right)$ troposphere is due to this region being significantly cleaner $\left(\mathrm{NO}_{x}\right.$ background levels of 5-20 pptv) compared to north polar $\left(60-90^{\circ} \mathrm{N}\right)$ troposphere (background levels of 20-50 pptv). As an aside, the SD-WACCM results, like those in Calisto et al. (2011), indicate a much smaller GCR-caused $\mathrm{NO}_{x}$ impact than computed in Semeniuk et al. (2011). Mironova et al. (2015) propose that "the absence of anthropogenic and natural $\mathrm{NO}_{x}$ emissions together with oversimplified tropospheric chemistry in CMAM" may be the reason for the larger response of the GCR perturbation in CMAM.

The GCR-caused ozone impact is shown in Fig. 4 (bottom) for SD-WACCM and in Fig. 5 (bottom) for the GSFC 2-D model. Ozone is mostly enhanced in the troposphere and lowest part of the stratosphere with largest increases of 1$2 \%$ from GCRs in the south polar troposphere in 2009. The GCR-caused ozone increase is due to two processes: (1) the NO reacting with $\mathrm{CH}_{4}$ oxidation products (see, also Krivolutsky et al., 2001):

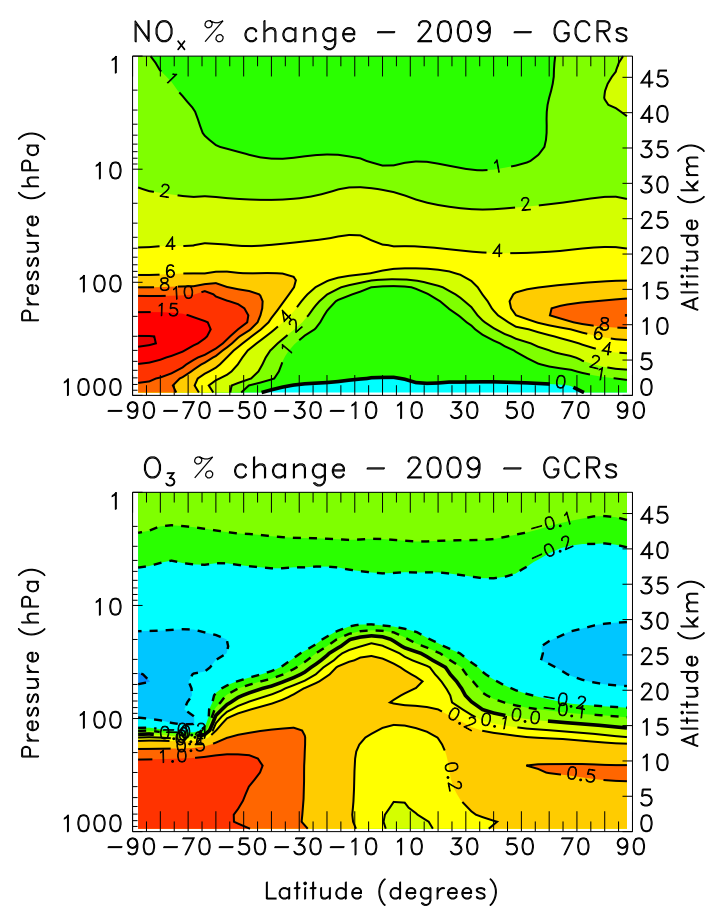

Figure 5. Annual average percentage change for year 2009 in zonal mean $\mathrm{NO}_{x}$ (top) and ozone (bottom) due to GCRs in the GSFC 2-D model (simulation B2_GCR_GSFC compared to B_Base_GSFC). The contour intervals for the $\mathrm{NO}_{x}$ changes are $0,1,2,4,6,8,10$, 15 , and $20 \%$. The contour intervals for the ozone changes are -1 , $-0.5,-0.2,-0.1,0,0.1,0.2,0.5$, and $1 \%$.

For example,

$$
\begin{aligned}
& \mathrm{CH}_{4}+\mathrm{OH} \rightarrow \mathrm{CH}_{3}+\mathrm{H}_{2} \mathrm{O} \\
& \mathrm{CH}_{3}+\mathrm{O}_{2}+\mathrm{M} \rightarrow \mathrm{CH}_{3} \mathrm{O}_{2}+\mathrm{M} \\
& \mathrm{CH}_{3} \mathrm{O}_{2}+\mathrm{NO} \rightarrow \mathrm{CH}_{3} \mathrm{O}+\mathrm{NO}_{2} \\
& \mathrm{NO}_{2}+h v \rightarrow \mathrm{NO}+\mathrm{O} \\
& \mathrm{O}+\mathrm{O}_{2}+\mathrm{M} \rightarrow \mathrm{O}_{3}+\mathrm{M} .
\end{aligned}
$$

and (2) the GCR-produced $\mathrm{NO}_{2}$ reacts with $\mathrm{ClO}$ to form $\mathrm{ClONO}_{2}$ and reduces the chlorine-caused ozone loss.

Ozone is decreased in most of the stratosphere due to the $\mathrm{NO}_{x}$ catalytic ozone depletion cycle:

$$
\begin{aligned}
& \mathrm{NO}+\mathrm{O}_{3} \rightarrow \mathrm{NO}_{2}+\mathrm{O}_{2} \\
& \mathrm{NO}_{2}+\mathrm{O} \rightarrow \mathrm{NO}+\mathrm{O}_{2}
\end{aligned}
$$

Net: $\mathrm{O}_{3}+\mathrm{O} \rightarrow \mathrm{O}_{2}+\mathrm{O}_{2}$.

GCR-caused $\mathrm{NO}_{x}$ increases of $\sim 1-6 \%$ are calculated for the lower stratosphere and cause ozone decreases of $0.2-$ $1 \%$. Our computed ozone impacts are similar to those previously discussed in Krivolutsky et al. (2001) and Calisto et al. (2011).

The computed impact of GCRs on $\mathrm{HO}_{x}$ and $\mathrm{HNO}_{3}$ using SD-WACCM is given in Fig. 6. Although GCRs produce $\mathrm{HO}_{x}$ (see Sect. 3), $\mathrm{HO}_{x}$ decreases are computed throughout 

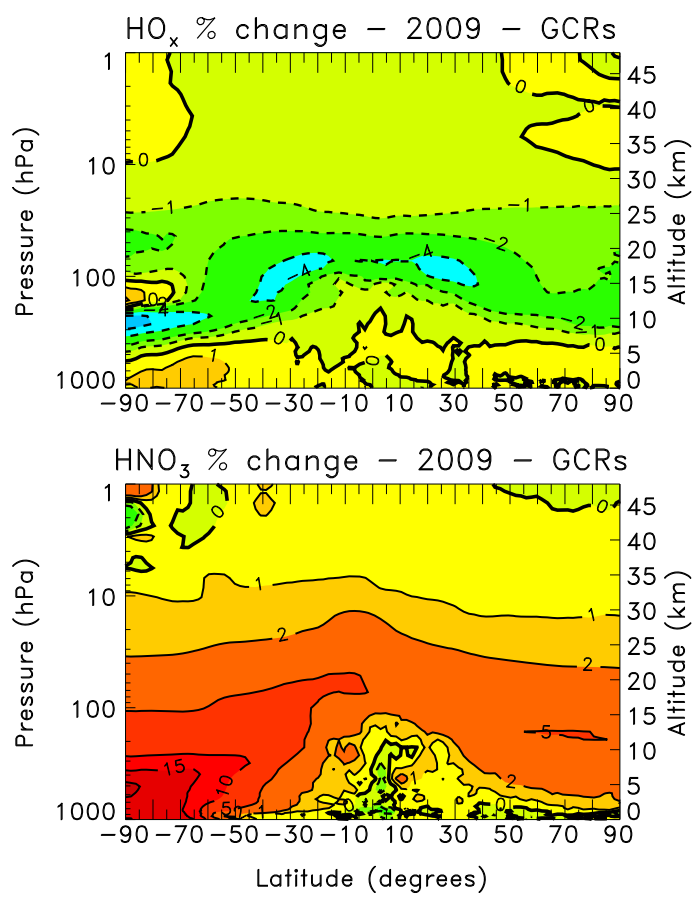

Figure 6. Annual average percentage change for year 2009 in zonal mean $\mathrm{HO}_{x}$ (top) and $\mathrm{HNO}_{3}$ (bottom) due to GCRs in the SDWACCM (simulation Base_SD_W compared to GCR_SD_W). The contour intervals for the $\mathrm{HO}_{x}$ changes are $-6,-4,-2,-1,0$, and $1 \%$. The contour intervals for the $\mathrm{HNO}_{3}$ are $-1,0,1,2,5,10,15$, and $20 \%$.

most of the atmosphere (Fig. 6, top). This is caused by the $\mathrm{NO}_{x}$ increases which remove $\mathrm{OH}$ via the reaction

$\mathrm{OH}+\mathrm{NO}_{2}+\mathrm{M} \rightarrow \mathrm{HNO}_{3}+\mathrm{M}$,

leading to $\mathrm{HNO}_{3}$ enhancements (Fig. 6, bottom). Again, these results are similar to those discussed in Calisto et al. (2011).

The SD-WACCM computations can also be used to address the question of the change in GCR influence over a solar cycle. The focus in this section has been on year 2009 since that was near solar minimum resulting in the maximum atmospheric influences caused by GCRs. The last previous solar maximum or GCR minimum occured in year 2002. Since the background atmosphere changes significantly from year 2002 to year 2009, it would be confusing to directly compare atmospheric changes between the 2 years to derive any GCR-caused change. Instead, the annual average percentage change from GCRs was computed for years 2002 and 2009 separately and then differenced from each other to illustrate the GCR-caused change over the solar cycle. The results are given in Fig. 7 for $\mathrm{NO}_{x}$ (top) and ozone (bottom) using simulations $G C R \_S D-W$ and $B A S E \_S D-W$. The computed GCR-induced solar cycle changes from 2002 to 2009 were slightly smaller than those computed for the GCRmaximum (solar minimum) year 2009. The GCR-caused
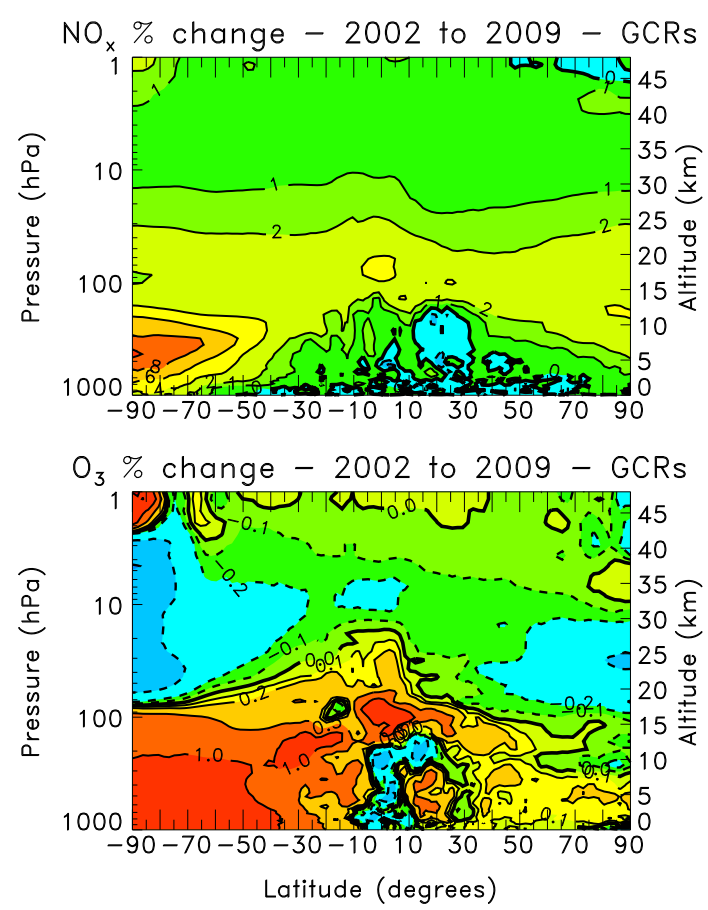

Figure 7. Annual average percentage change from year 2002 (solar maximum) to 2009 (solar minimum) in zonal mean $\mathrm{NO}_{x}$ (top) and ozone (bottom) in the SD-WACCM. Simulations GCR_SD-W and Base_SD-W were used for this comparison. The annual average percentage change from GCRs was computed for years 2002 and 2009 separately and then differenced from each other. The contour intervals for the $\mathrm{NO}_{x}$ changes are $0,1,2,4,6,8$, and $10 \%$. The contour intervals for the ozone changes are $-1,-0.5,-0.2,-0.1$, $0,0.1,0.2,0.5$, and $1 \%$.

changes are proportional to the GCR-caused ion pair production, which is given in Fig. 1 for the years 2002 and 2009. Note that the largest ion pair production near the south pole is over $30 \mathrm{~cm}^{-3} \mathrm{~s}^{-1}$ in 2009 and is nearly $15 \mathrm{~cm}^{-3} \mathrm{~s}^{-1}$ in 2002 . Thus, there is a difference of about $15 \mathrm{~cm}^{-3} \mathrm{~s}^{-1}$ from 2002 to 2009 versus a difference of $30 \mathrm{~cm}^{-3} \mathrm{~s}^{-1}$ for 2009 in a comparison without GCRs to with GCRs.

\subsection{Time-dependent total ozone changes}

The GSFC 2-D model gives fairly similar results to SDWACCM (compare Figs. 4 and 5) and is significantly faster computationally to use for longer-term simulations. Thus, the GSFC 2-D model was used in several sensitivity study simulations described in Table 1 (and Sect. 4.2) to investigate the longer term GCR-caused changes, particularly focusing on annual average global total ozone (AAGTO) as well as global column ozone in the two regions between 1000 and $100 \mathrm{hPa}$ and between 100 and $1 \mathrm{hPa}$. The GCR-caused change in ozone in those two regions, separately, and for the entire troposphere and stratosphere $(1000-1 \mathrm{hPa})$ is computed for two pairs of scenarios: (1) Fig. 8 (top) shows a com- 

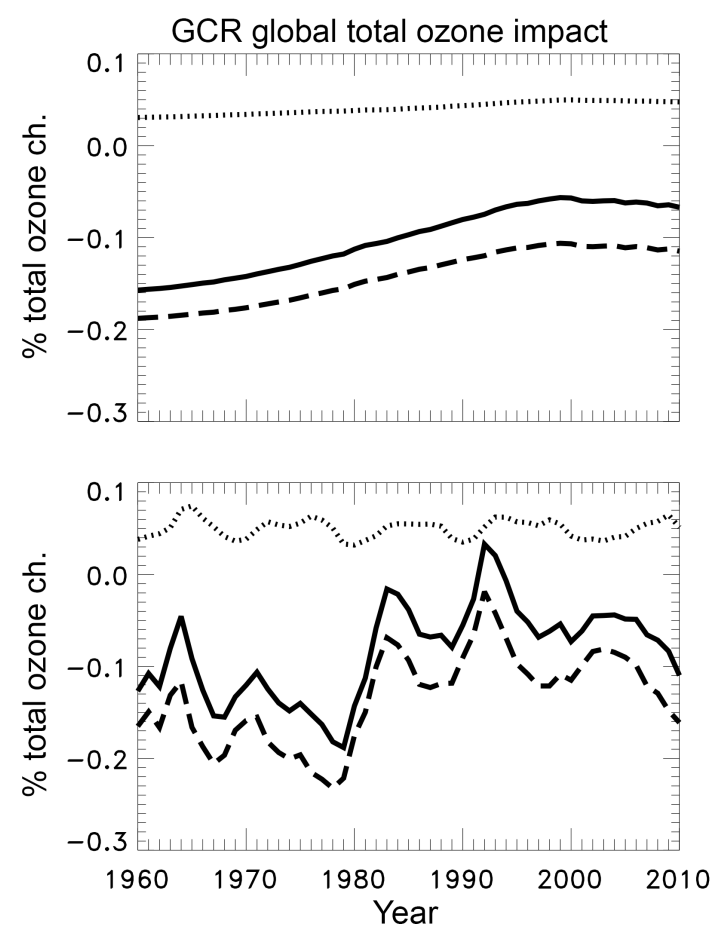

Figure 8. GSFC 2-D model GCR-computed impacts of AAGTO between 1000 and $100 \mathrm{hPa}$ (dotted black), between 100 and $1 \mathrm{hPa}$ (dashed black), and for the entire troposphere and stratosphere, 1000 to $1 \mathrm{hPa}$, (solid black) over the 1960-2010 time period. The top plot shows the comparison of simulation A1_GCR_GSFC to A_Base_GSFC. The bottom plot shows the comparison of simulation E_GCR_GSFC to E_Base_GSFC.

parison of the first pair (A1_GCR_GSFC to $A \_B a s e \_G S F C$ ), which are simplified representations of the atmosphere with a climatological mean transport (changes daily, but repeats yearly) in both scenarios and a mean GCR input (constant throughout the simulation) in A1_GCR_GSFC; and (2) Fig. 8 (bottom) shows a comparison of the most comprehensive pair (E_GCR_GSFC to $E \_B a s e \_G S F C$ ), which include interannually varying transport, sulfate aerosol surface area, and solar cycle photon flux variation in both scenarios and an interannually varying GCR input in $E_{-} G C R \_G S F C$.

First, focus on the results intercomparing scenarios $A l_{-}$ GCR_GSFC to A_Base_GSFC (see Fig. 8, top): the GCRcaused column ozone between 1000 and $100 \mathrm{hPa}$ showed an increase from +0.03 up to $\sim+0.05 \%$ over the 1960-2010 time period, driven partly by increases in $\mathrm{CH}_{4}$ over those 51 years. The GCR-caused column ozone between 100 and $1 \mathrm{hPa}$ also showed a time-dependent increase, but started in year 1960 at $-0.19 \%$ ending up at $-0.12 \%$ in year 2010 . The GCR-caused total AAGTO follows the increases in the two regions noted above, starting at $-0.16 \%$ in year 1960 and increasing to $\sim-0.07 \%$ in year 2010 .

Second, intercompare the more complete simulations E_GCR_GSFC to E_Base_GSFC (see Fig. 8, bottom): the
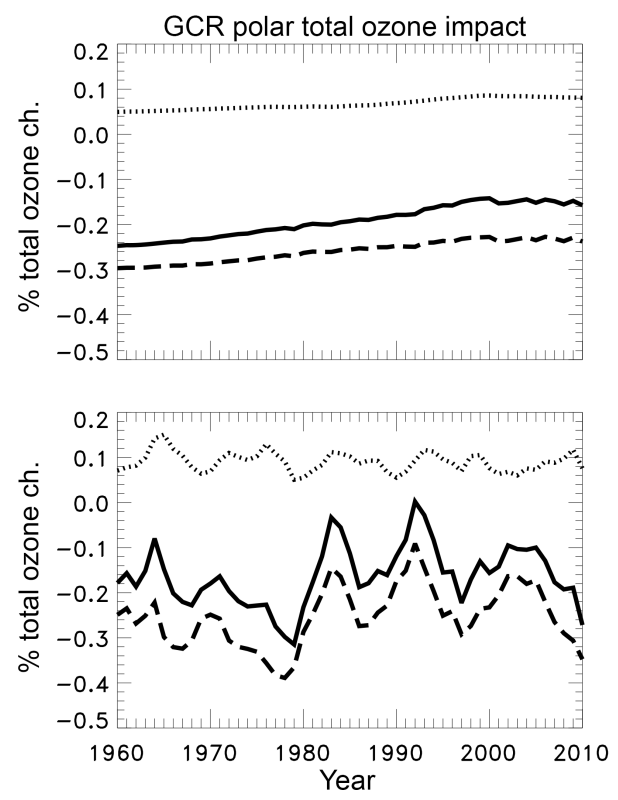

Figure 9. GSFC 2-D model GCR-computed impacts of annual average polar total ozone (AAPTO) between 1000 and $100 \mathrm{hPa}$ (dotted black), between 100 and $1 \mathrm{hPa}$ (dashed black), and for the entire troposphere and stratosphere, 1000 to $1 \mathrm{hPa}$, (solid black) over the 1960-2010 time period. The top plot shows the comparison of simulation A1_GCR_GSFC to A_Base_GSFC. The bottom plot shows the comparison of simulation $E \_G C R \_G S F C$ to $E \_B a s e \_G S F C$.

GCR-caused column ozone changes between 1000 and $100 \mathrm{hPa}$ showed a significant variation from $\sim+0.03$ to $\sim$ $+0.07 \%$ over the 1960-2010 time period. The GCR-caused column ozone changes between 100 and $1 \mathrm{hPa}$ also showed substantial variation giving $-0.23 \%$ in 1979 and $-0.02 \%$ in 1992. The GCR-caused total AAGTO followed these variations, with a low of $-0.19 \%$ in 1979 and a high of $+0.03 \%$ in 1992.

The GCR-caused atmospheric changes are larger at higher latitudes, thus we also compute the annual average polar total ozone (AAPTO). The AAPTO is calculated using the model output only at polar latitudes $\left(60-90^{\circ} \mathrm{S}\right.$ and $\left.60-90^{\circ} \mathrm{N}\right)$ and is given in Fig. 9. Both the AAGTO (Fig. 8) and the AAPTO (Fig. 9) have similar shapes for the total ozone change in the two regions plotted (1000-100 and 100-1 hPa). In 1960 the AAGTO for the entire troposphere and stratosphere (1000$1 \mathrm{hPa}$ ) is computed to be $-0.13 \%$ (see Fig. 8 , bottom) while the AAPTO is computed to be $-0.18 \%$ (see Fig. 9, bottom). In 2010 the AAGTO for the troposphere and stratosphere is computed to be $-0.11 \%$ (see Fig. 8, bottom) while the AAPTO is computed to be $-0.27 \%$ (see Fig. 9, bottom). Thus, the polar differences tend to be larger by the end than they were at the start of the simulation period.

The impact of five simultaneous atmospheric changes are responsible for the GCR-caused variations in AAGTO observed in Fig. 8 (bottom). These changes are (1) background total chlorine; (2) sulfate aerosol surface area; (3) solar cy- 

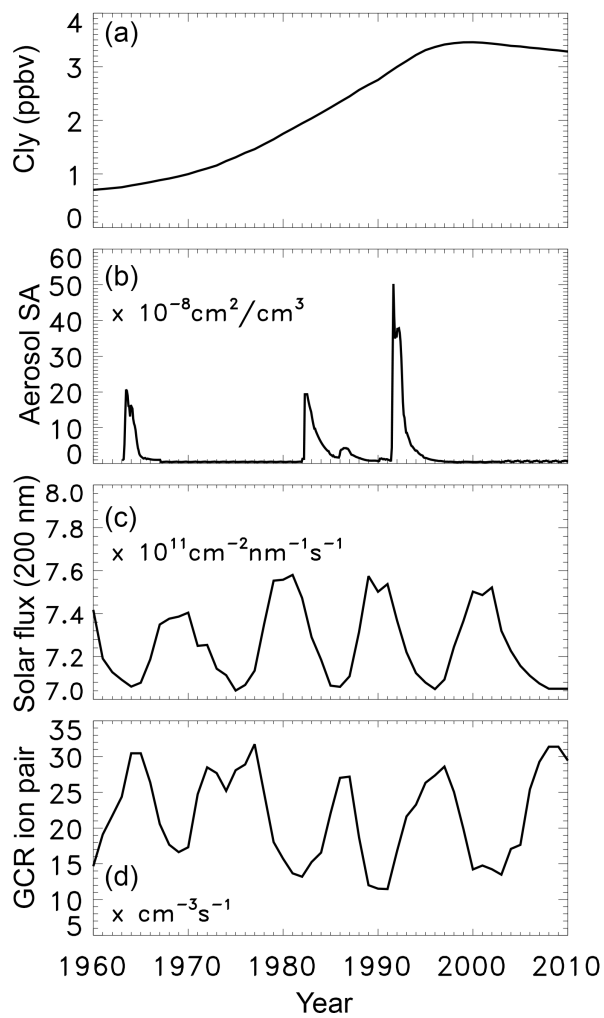

Figure 10. Forcing used in the GSFC 2-D model over the 19602010 time period. These include: (a) background total chlorine $\left(\mathrm{Cl}_{y}\right.$, in ppbv); (b) aerosol surface area (SA) at $50 \mathrm{hPa}$ and the Equator in $10^{-8} \mathrm{~cm}^{2} \mathrm{~cm}^{-3}$; (c) solar flux at $200 \mathrm{~nm}$ in $10^{11} \mathrm{~cm}^{-2} \mathrm{~nm}^{-1} \mathrm{~s}^{-1}$; and (d) GCR ion pair production at $200 \mathrm{hPa}$ and $90^{\circ} \mathrm{S}$ in $\mathrm{cm}^{-3} \mathrm{~s}^{-1}$.

cle photon flux variation; (4) solar cycle GCR variation; and (5) interannual transport variability. Background total chlorine increases dramatically from 0.7 to $3.5 \mathrm{ppbv}$ over the 1960-2010 period (Fig. 10a, Equator, $1 \mathrm{hPa}$ ). Volcanoes can add substantially to the aerosol surface area during certain years (especially 1963, 1982, and 1991, see Fig. 10b). The photon flux varies over the solar cycle and is especially important to the stratosphere at ultraviolet wavelengths. The solar flux variation at $200 \mathrm{~nm}$ (up to about $8.5 \%$ from solar minimum to maximum) is important for ozone production and is shown in Fig. 10c. The GCRs vary over the solar cycle as well and the GCR-caused ion pair production is given in Fig. $10 \mathrm{~d}$ at $200 \mathrm{hPa}$ and $90^{\circ} \mathrm{S}$. The final atmospheric variation is due to the interannual transport variability over the whole time period, which is difficult to illustrate in a line plot (like those given in Fig. 10).

\subsubsection{Background total chlorine}

The smoothest change over the 1960-2010 time period occurred with the amount of background total chlorine. The AAGTO has been computed for the six scenar- ios (A_Base_GSFC, A1_GCR_GSFC, A2_GCR_GSFC, B_Base_GSFC, B1_GCR_GSFC, B2_GCR_GSFC) for use in this analysis. Percentage differences in AAGTO for $A 1$ GCR_GSFC compared to $A \_B a s e \_G S F C$ are shown in Fig. 11a (black solid line) compared with background total chlorine (red solid line). Note the good correspondence between background total chlorine amount and GCR-caused AAGTO change. Smaller amounts of background total chlorine correlate with larger computed GCR-caused AAGTO decrease and vice versa.

First, this is partly a reflection of the role that chlorine, through the $\mathrm{ClO}_{x}$ catalytic cycle

$\mathrm{Cl}+\mathrm{O}_{3} \rightarrow \mathrm{ClO}+\mathrm{O}_{2}$

$\mathrm{ClO}+\mathrm{O} \rightarrow \mathrm{Cl}+\mathrm{O}_{2}$

Net: $\mathrm{O}_{3}+\mathrm{O} \rightarrow \mathrm{O}_{2}+\mathrm{O}_{2}$,

has in controlling stratospheric ozone over this time period. At low levels of chlorine, the $\mathrm{NO}_{x}$ catalytic cycle is more important to ozone control. Thus, increases in $\mathrm{NO}_{x}$, such as caused by GCRs, lead to a more significant ozone response in the 1960s than in the 2000s when the background total chlorine amounts are much higher.

Second, this is also a reflection of the interference of the $\mathrm{NO}_{x}$ family with the $\mathrm{ClO}_{x}$ catalytic cycle through the reaction

$\mathrm{ClO}+\mathrm{NO}_{2}+\mathrm{M} \rightarrow \mathrm{ClONO}_{2}+\mathrm{M}$.

Increased $\mathrm{NO}_{x}$ amounts caused by GCRs will lead to an increased production of the reservoir constituent, $\mathrm{ClONO}_{2}$, and thus less ozone destruction.

Both of these processes are ongoing in the atmosphere and are reflected in Fig. 11a, which illustrates most clearly the correlation between the GCR-caused change in ozone and background total chlorine amount.

Figure $11 \mathrm{~b}$ shows the results of the AAGTO computed in B1_GCR_GSFC compared to B_Base_GSFC. The main difference here is that the model transport changes interannually. There still is a correlation between high background total chlorine amounts and less AAGTO change caused by the GCRs.

Figure $11 \mathrm{c}$ illustrates the results of a comparison of the AAGTO computed in A2_GCR_GSFC compared to A_Base_GSFC. Both simulations have the same mean transport imposed over the 51-year time period, however, the GCRs are forced with interannually varying GCRs (see Fig. 10d). Again, there is a correspondence between the amount of background total chlorine and the GCR-caused AAGTO change.

Finally, Fig. 11d illustrates the results of a comparison of the AAGTO computed in B2_GCR_GSFC compared to $B \_B a s e \_G S F C$. Both simulations have interannual transport and the simulation with GCRs (B2_GCR_GSFC) includes the interannual variation of GCRs. Although there is clearly 


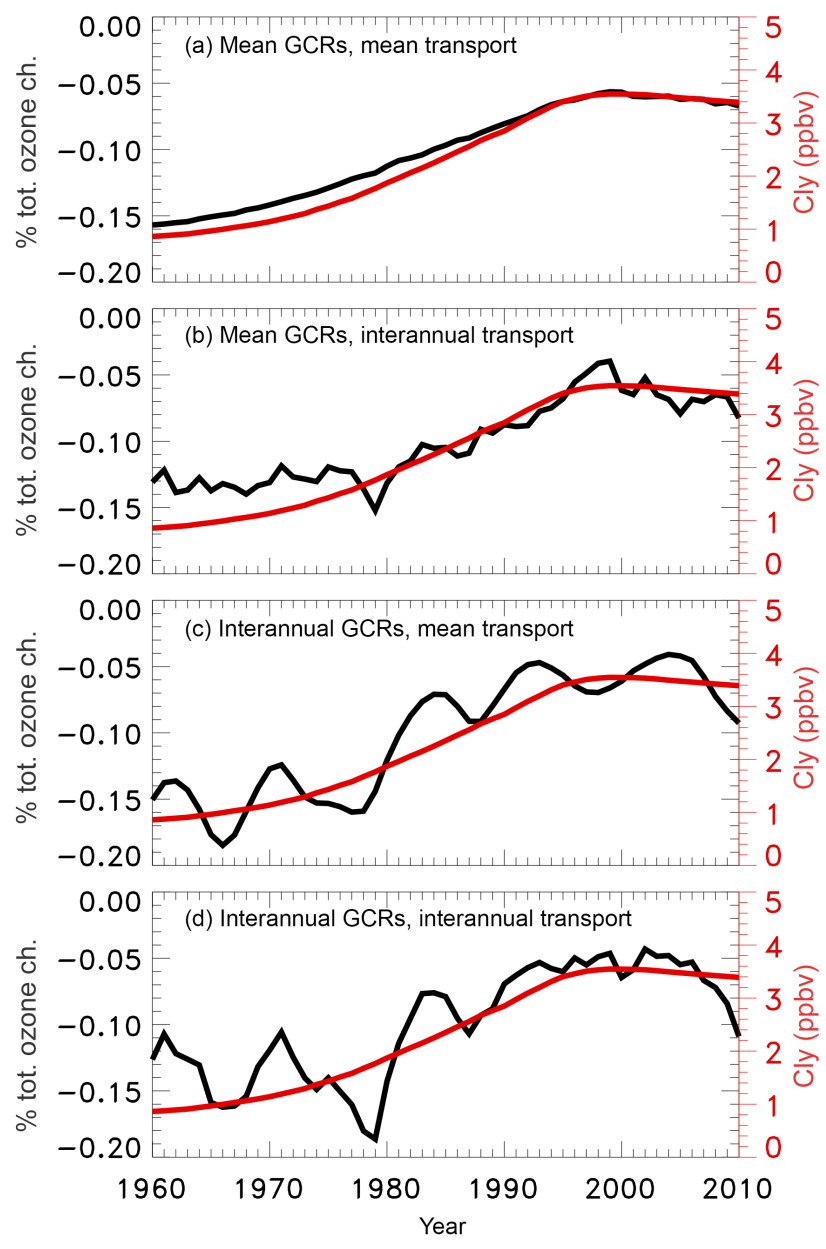

Figure 11. GSFC 2-D model GCR-computed AAGTO impacts (black lines) over the 1960-2010 time period. The $\mathrm{Cl}_{y}$ levels are also shown (red lines). The GSFC 2-D model comparisons include (a) mean GCRs, mean transport (simulation A1_GCR_GSFC compared to A_Base_GSFC); (b) mean GCRs, interannual transport (simulation B1_GCR_GSFC compared to B_Base_GSFC); (c) interannual GCRs, mean transport (simulation $A 2 \_G C R \_G S F C$ compared to $\left.A \_B a s e \_G S F C\right)$; and (d) interannual GCRs, interannual transport (simulation $B 2 \_G C R \_G S F C$ compared to $B \_B a s e \_G S F C$ ).

more year-to-year variability, it is apparent that higher background total chlorine levels lead to less GCR-caused ozone changes.

\subsubsection{Aerosol surface area}

The aerosol surface area varies dramatically over the 19602010 time period. Volcanoes in years 1963, 1982, and 1991 caused large increases in the aerosol surface area. Enhanced aerosol surface area results in an increase in heterogeneous reactions on the sulfate aerosols. In particular, the reaction

$\mathrm{N}_{2} \mathrm{O}_{5}+\mathrm{H}_{2} \mathrm{O} \rightarrow 2 \mathrm{HNO}_{3}$

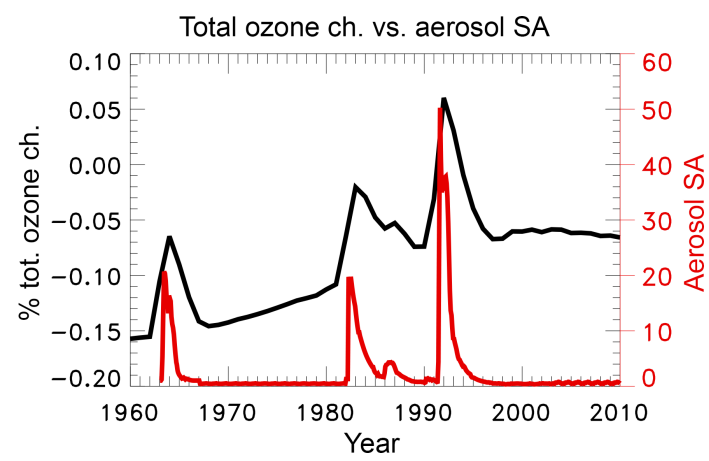

Figure 12. GSFC 2-D model GCR-computed AAGTO impacts (black line) over the 1960-2010 time period (simulation C_GCR_GSFC compared to C_Base_GSFC). The aerosol surface area (SA) at $50 \mathrm{hPa}$ and the Equator is also shown (red lines), given in $10^{-8} \mathrm{~cm}^{2} \mathrm{~cm}^{-3}$.

proceeds rapidly, removing the more active $\mathrm{NO}_{x}$ constituents and producing the less active $\mathrm{HNO}_{3}$ reservoir constituent. The result of this is that $\mathrm{NO}_{x}$ production from any source is less efficient. A comparison of the AAGTO computed in $C_{-} G C R \_G S F C$ compared to C_Base_GSFC is shown in Fig. 12. This shows that the GCRs cause a less negative change (even positive in 1992-1993) in AAGTO during the years of enhanced aerosol surface area.

\subsubsection{Solar cycle photon variation}

The sun not only influences the GCR flux over a solar cycle, but it also shows a significant variation in solar photons and solar particles (electrons, protons and other particles). The photon flux variation and its impact on the GCR effect will be addressed here. However, it is outside the scope of this paper to discuss the influence of solar energetic particles (e.g., protons, other ions, and electrons) on the GCR-caused atmospheric influence.

The solar cycle variation led to changes in the photon flux, especially at the X-ray, extreme ultraviolet, and ultraviolet wavelengths. In particular, the stratosphere is greatly influenced by photons at ultraviolet wavelengths (e.g., $200 \mathrm{~nm}$ photons are important in producing ozone) and a variation of up to about $8.5 \%$ from solar minimum to maximum was shown in Fig. 10c. A comparison of the AAGTO computed in $D \_G C R \_G S F C$ was compared to D_Base_GSFC. These simulations isolated the impact of the solar cycle photon variation on the GCR influence. Only a very minor change ( $\pm 0.004 \%$ in AAGTO) was found to be forced by the solar cycle photon flux variation (not shown).

\subsubsection{GCR interannual and solar cycle driven variation}

The GCRs vary from year-to-year, influenced primarily by the strength of the solar magnetic field. The GCR variation (given in ion pair production) can be as large as a factor of 
two at the poles (see Fig. 10d). Most of the impact from GCRs is in the polar lower stratosphere/upper troposphere, since the GCR caused ionization rates peak there (see Fig. 1). The residence time for constituents in the lower stratosphere is long ( $\sim 1$ year or so, which is driven by the transport) as is the photochemical time constant for odd oxygen (essentially ozone) in this region (e.g., see Fig. 5.3, Brasseur and Solomon, 1995), thus the computed impact of the GCRs on the atmosphere will be a time-lagged average of the GCR input. The AAGTO shown in Fig. 11c was differenced from that shown in Fig. 11a in order to compute the change caused by the interannual GCR variation. This interannually driven GCR change in AAGTO is represented by the black line in Fig. 13. The red line in Fig. 13 is a 2-year boxcar (running) average of the GCR ion pair production (in $\mathrm{cm}^{-3} \mathrm{~s}^{-1}$ ) at $200 \mathrm{hPa}$ and $90^{\circ} \mathrm{S}$ with a 1-year lag and appears to be an anti-correlation of the AAGTO change. Thus, the impact of the interannual variation in the GCRs with an imposed 1year time lag and 2-year average can represent the computed AAGTO change fairly well.

\subsubsection{Interannual transport variation}

The interannual transport variation drives changes in the impact of the GCRs on the AAGTO. This interannual behavior is best observed in Fig. 11b, where the mean GCRs are imposed continuously over the entire 51-year time period. Variations of up to $\sim 0.04 \%$ in the GCR-caused AAGTO impact are computed over a couple of years or so. However as noted in Sect. 5.3.1, the strong correlation between high background total chlorine amounts and less AAGTO change caused by the GCRs dominates so that the interannual transport changes have only a very small effect on the time-dependent GCR-induced AAGTO impact.

\subsection{NO $\mathrm{N}_{y}$ production}

The total $\mathrm{NO}_{y}$ produced per year from GCRs was compared with that from other sources. GSFC 2-D model calculations show that $\mathrm{N}_{2} \mathrm{O}$ oxidation $\left(\mathrm{N}_{2} \mathrm{O}+\mathrm{O}\left({ }^{1} \mathrm{D}\right) \rightarrow \mathrm{NO}+\mathrm{NO}\right)$ produce 43.5-55.7 GigaMoles of $\mathrm{NO}_{y}$ with the vast majority (greater than $90 \%$ ) produced in the stratosphere. GCRs were computed to produce 3.1-6.4 GigaMoles of $\mathrm{NO}_{y}$, with 40$50 \%$ of that produced in the stratosphere. Thus, GCRs can be responsible for as much as $14 \%$ of the total $\mathrm{NO}_{y}$ production, however on average, GCRs produce about 3-6\% of stratospheric $\mathrm{NO}_{y}$ in any given year. This is somewhat less than that found by Vitt and Jackman (1996), who computed that GCRs were responsible for $9-12 \%$ of the total stratospheric $\mathrm{NO}_{y}$ produced per year. The Vitt and Jackman (1996) computations used ion pair production rates from a parameterization based on yearly averaged sunspot number from Nicolet (1975), which are generally larger than those GCRcaused ion pair production rates computed with the more re-

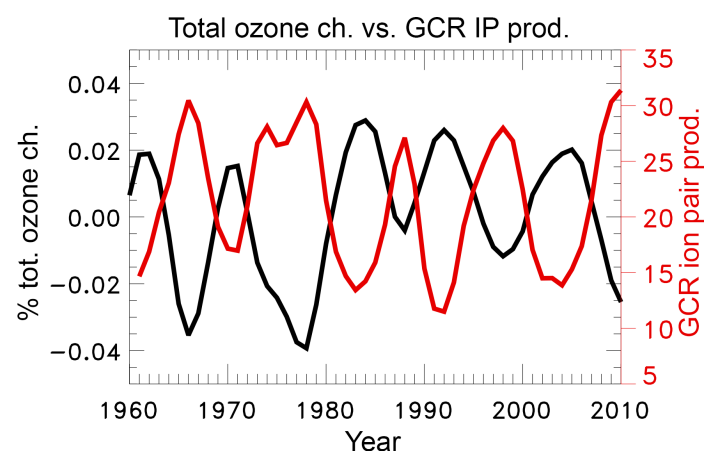

Figure 13. GSFC 2-D model GCR-computed AAGTO change (black line) over the 1960-2010 time period caused by the interannual GCR variation. The global total ozone change shown in Fig. 11c is differenced from that shown in Fig. 11a. A 2-year boxcar (running) average of the GCR ion pair production (in $\mathrm{cm}^{-3} \mathrm{~s}^{-1}$ ) at $200 \mathrm{hPa}$ and $90^{\circ} \mathrm{S}$ with a 1-year lag is also shown (red line).

cent NAIRAS model used in the present study (discussed in Sect. 2).

\section{Conclusions}

Two global models, SD-WACCM and GSFC 2-D, were used to study the atmospheric impact of GCRs over the 1960 2010 time period. The largest atmospheric impacts occurred in the $\mathrm{NO}_{x}$ constituents, which had maximum GCR-caused increases of 4-15\% in the Southern polar troposphere. There were associated ozone increases of $1-2 \%$ correlated with these $\mathrm{NO}_{x}$ enhancements. The lower stratosphere was also impacted with computed $\mathrm{NO}_{x}$ increases of $\sim 1-6 \%$ causing associated ozone decreases of $0.2-1 \%$. GCR-caused decreases of AAGTO were computed to be $0.2 \%$ or less with GCR-caused column ozone increases between 1000 and $100 \mathrm{hPa}$ of $0.08 \%$ or less and GCR-caused column ozone decreases between 100 and $1 \mathrm{hPa}$ of $0.23 \%$ or less. There appears to be a time lag of about a year between the GCRcaused $\mathrm{NO}_{x}$ production and the resultant AAGTO change. This is consistent with the long residence and photochemical time constant of ozone in the lower stratosphere. The impact of GCRs has a strong correlation with the atmospheric chlorine loading, sulfate aerosol loading, and solar cycle variation. GCRs cause larger atmospheric impacts with less chlorine loading, less sulfate aerosol loading, and for years closer to solar minimum. This result serves as a lower limit because of the use of the ionization model NAIRAS/HZETRN which underestimates the ion production by neglecting electromagnetic and muon branches of the cosmic ray induced cascade. This will be corrected in future works. 
Acknowledgements. Charles H. Jackman, Daniel R. Marsh, Douglas E. Kinnison, Christopher J. Mertens, and Eric L. Fleming thank the NASA Headquarters Living With a Star Targeted Research and Technology Program for support during the time that this manuscript was written. Charles H. Jackman and Eric L. Fleming were also supported by the NASA Headquarters Atmospheric Composition Modeling and Analysis Program. The National Center for Atmospheric Research (NCAR) is sponsored by the US National Science Foundation. WACCM is a component of the Community Earth System Model (CESM), which is supported by the National Science Foundation (NSF) and the Office of Science of the US Department of Energy. Computing resources were provided by NCAR's Climate Simulation Laboratory, sponsored by NSF and other agencies. This research was enabled by the computational and storage resources of NCAR's Computational and Information System Laboratory (CISL).

Edited by: M. Palm

\section{References}

Badhwar, G. D. and O'Neill, P. M.: An improved model of galactic cosmic radiation for space exploration missions, Nucl. Tracks Rad. Meas., 20, 403-410, 1992.

Badhwar, G. D. and O'Neill, P. M.: Long term modulation of galactic cosmic radiation and its model for space exploration, Adv. Space Res., 14, 749-757, 1994.

Badhwar, G. D. and O'Neill, P. M.: Galactic cosmic radiation model and its applications, Adv. Space Res., 17, 7-17, 1996.

Brasseur, G. and Solomon, S.: Aeronomy of the Middle Atmosphere: Chemistry and Physics of the Stratosphere and Mesosphere, D. Reidel Publishing Company, Dordrecht, the Netherlands, 1995.

Calisto, M., Usoskin, I., Rozanov, E., and Peter, T.: Influence of Galactic Cosmic Rays on atmospheric composition and dynamics, Atmos. Chem. Phys., 11, 4547-4556, doi:10.5194/acp-114547-2011, 2011.

Considine, D. B., Douglass, A. R., and Jackman, C. H.: Effects of a polar stratospheric cloud parameterization on ozone depletion due to stratospheric aircraft in a two-dimensional model, J. Geophys. Res., 99, 18879-18894, 1994.

Douglass, A. R., Jackman, C. H., and Stolarski, R. S.: Comparison of model results transporting the odd nitrogen family with results transporting separate odd nitrogen species, J. Geophys. Res., 94, 9862-9872, 1989.

Duncan, B. N., Strahan, S. E., Yoshida, Y., Steenrod, S. D., and Livesey, N.: Model study of the cross-tropopause transport of biomass burning pollution, Atmos. Chem. Phys., 7, 3713-3736, doi:10.5194/acp-7-3713-2007, 2007.

Emmons, L. K., Walters, S., Hess, P. G., Lamarque, J.-F., Pfister, G. G., Fillmore, D., Granier, C., Guenther, A., Kinnison, D., Laepple, T., Orlando, J., Tie, X., Tyndall, G., Wiedinmyer, C., Baughcum, S. L., and Kloster, S.: Description and evaluation of the Model for Ozone and Related chemical Tracers, version 4 (MOZART-4), Geosci. Model Dev., 3, 43-67, doi:10.5194/gmd3-43-2010, 2010.

Eyring, V., Lamarque, J.-F., Hess, P., Arfeuille, F., Bowman, K., Chipperfield, M., Duncan, B., Fiore, A., Gettelman, A., Gior- getta, M., Granier, C., Hegglin, M., Kinnison, D., Kunze, M., Langematz, U., Luo, B., Martin, R., Matthes, K., Newman, P., Peter, T., Robock, A., Ryerson, T., Saiz-Lopez, A., Salawitch, R., Schultz, M., Shepherd, T. G., Shindell, D., Staehelin, J., Tegtmeier, S., Thomason, L., Tilmes, S., Vernier, J.-P., Waugh, D. W., and Young, P. J.: Overview of IGAC/SPARC Chemistry-Climate Model Initiative (CCMI) Community Simulations in Support of Upcoming Ozone and Climate Assessments, SPARC newsletter, Zurich, Switzerland, 40, 48-66, January 2013.

Finlay, C. C., Maus, S., Beggan, C. D., Bondar, T. N., Chambodut, A., Chernova, T. A.,Chulliat, A., Golovkov, V. P., Hamilton, B., Hamoudi, M., Holme, R., Hulot, G., Kuang, W., Langlais, B., Lesur, V., Lowes, F. J., Lühr, H., Macmillan, S., Mandea, M., McLean, S., Manoj, C., Menvielle, M., Michaelis, I., Olsen, N., Rauberg, J., Rother, M., Sabaka, T. J., Tangborn, A., TøffnerClausen, L.,Thébault, E., Thomson, A. W. P., Wardinski, I., Wei, Z., and Zvereva, T. I.: International Geomagnetic Reference Field: the eleventh generation, Geophys. J. Int., 183, 1216-1230, doi:10.1111/j.1365-246X.2010.04804.x, 2010.

Fleming, E. L., Jackman, C. H., Considine, D. B., and Stolarski, R. S.: Simulation of stratospheric tracers using an improved empirically based two-dimensional model transport formulation, J. Geophys. Res., 104, 23911-23934, 1999.

Fleming, E. L., Jackman, C. H., Weisenstein, D. K., and Ko, M. K. W.: The impact of inter-annual variability on multidecadal total ozone simulations, J. Geophys. Res., 112, D10310, doi:10.1029/2006JD007953, 2007.

Fleming, E. L., Jackman, C. H., Stolarski, R. S., and Douglass, A. R.: A model study of the impact of source gas changes on the stratosphere for 1850-2100, Atmos. Chem. Phys., 11, 8515-8541, doi:10.5194/acp-11-8515-2011, 2011.

Fleming, E. L., George, C., Heard, D. E., Jackman, C. H., Kurylo, M. J., Mellouki, W., Orkin, V. L., Swartz, W. H., Wallington, T. J., Wine, P. H., and Burkholder, J. B.: The impact of current $\mathrm{CH}_{4}$ and $\mathrm{N}_{2} \mathrm{O}$ atmospheric loss process uncertainties on calculated ozone abundances and trends, J. Geophys. Res.-Atmos., 120, 5267-5293, doi:10.1002/2014JD022067, 2015.

Garcia, R. R., Solomon, S., Roble, R. G., and Rusch, D. W.: A numerical response of the middle atmosphere to the 11 year solar cycle, Planet. Space Sci., 32, 411-423, 1984.

Jackman, C. H.: Effects of energetic particles on minor constituents of the middle atmosphere, J. Geomag. Geoelectr., 43, 637-646, 1991.

Jackman, C. H.: Energetic particle influences on $\mathrm{NO}_{y}$ and Ozone in the middle atmosphere, Interactions Between Global Climate Subsystems, The Legacy of Hann, Geophysical Monograph 75, IUGG Volume 15, 131-139, 1993.

Jackman, C. H., Frederick, J. E., and Stolarski, R. S.: Production of odd nitrogen in the stratosphere and mesosphere: an intercomparison of source strengths, J. Geophys. Res., 85, 7495-7505, 1980.

Jackman, C. H., Guthrie, P. D., and Kaye, J. A.: An intercomparison of nitrogen-containing species in Nimbus 7 LIMS and SAMS data, J. Geophys. Res., 92, 995-1008, 1987.

Jackman, C. H., Douglass, A. R., Rood, R. B., McPeters, R. D., and Meade, P. E.: Effect of solar proton events on the middle atmosphere during the past two solar cycles as computed using a twodimensional model, J. Geophys. Res., 95, 7417-7428, 1990. 
Jackman, C. H., Fleming, E. L., Chandra, S., Considine, D. B., and Rosenfield, J. E.: Past, present, and future modeled ozone trends with comparisons to observed trends, J. Geophys. Res., 101, 28753-28767, 1996.

Jackman, C. H., DeLand, M. T., Labow, G. J., Fleming, E. L., Weisenstein, D. K., Ko, M. K. W., Sinnhuber, M., and Russell, J. M.: Neutral atmospheric influences of the solar proton events in October-November 2003, J. Geophys. Res., 110, A09S27, doi:10.1029/2004JA010888, 2005.

Kalnay, E., Kanamitsu, M., Kistler, R., Collins, W., Deaven, D., Gandin, L., Iredell, M., Saha, S., White, G., Woollen, J., Zhu, Y., Chelliah, M., Ebizusaki, W., Higgins, W., Janowiak, J., Mo, K. C., Ropelewski, C., Wang, J., Leetmaa, A., Reynolds, R., Jenne, R., and Joseph, D.: The NCEP/NCAR 40 year reanalysis project, B. Am. Meteorol. Soc., 77, 437-471, 1996.

Kistler, R., Collins, W., Saha, S., White, G., Woollen, J., Kalnay, E., Chelliah, M., Ebizusaki, W., Kanamitsu, M., Kousky, V., van den Dool, H., Jenne, R., and Fiorino, M.: The NCEP-NCAR 50 year reanalysis: monthly means $\mathrm{CD}-\mathrm{ROM}$ and documentation, B. Am. Meteorol. Soc., 82, 247-267, 2001.

Kinnison, D. E., Brasseur, G. P., Walters, S., Garcia, R. R., Marsh, D. R., Sassi, F., Harvey, V. L., Randall, C. E., Emmons, L., Lamarque, J. F., Hess, P., Orlando, J. J., Tie, X. X., Randel, W., Pan, L. L., Gettelman, A., Granier, C., Diehl, T., Niemeier, U., and Simmons, A. J.: Sensitivity of chemical tracers to meteorological parameters in theMOZART-3 chemical transport model, J. Geophys. Res., 112, D20302, doi:10.1029/2006JD007879, 2007

Krivolutsky, A. A., Kuminov, A. A., and Repnev, A. I.: Effects of cosmic rays on the earth's ozonosphere: a review, Geomagn. Aeronomy, 39, 271-282, 1999.

Krivolutsky, A. A., Bazilevskaya, G. A., Vyushkova, T. Y., and Knyazeva, G. V.: Long-term tropospheric variations of ozone content caused by galactic cosmic ray influence, Adv. Space Res., 27, 2019-2024, 2001.

Krivolutsky, A., Bazilevskaya, G., Vyushkova, T., and Knyazeva, G.: Influence of cosmic rays on chemical composition of the atmosphere: data analysis and photochemical modeling, Phys. Chem. Earth, 27, 471-476, 2002.

Kunz, A., Pan, L., Konopka, P., Kinnison, D. E., and Tilmes, S.: Chemical and dynamical discontinuity at the extratropical tropopause based on START08 and WACCM analysis, J. Geophys. Res., 116, D24302, doi:10.1029/2011JD016686, 2011.

Lamarque, J.-F., Emmons, L. K., Hess, P. G., Kinnison, D. E., Tilmes, S., Vitt, F., Heald, C. L., Holland, E. A., Lauritzen, P. H., Neu, J., Orlando, J. J., Rasch, P. J., and Tyndall, G. K.: CAMchem: description and evaluation of interactive atmospheric chemistry in the Community Earth System Model, Geosci. Model Dev., 5, 369-411, doi:10.5194/gmd-5-369-2012, 2012.

Legrand, M. R., Stordal, F., Isaksen, I. S. A., and Rognerud, B.: A model study of the stratospheric budget of odd nitrogen, including effects of solar cycle variations, Tellus B, 41, 413-426, 1989.

McPeters, R. D., Labow, G. J., and Logan, J. A.: Ozone climatological profiles for satellite retrieval algorithms, J. Geophys. Res., 112, D05308, doi:10.1029/2005JD006823, 2007.

Mertens, C. J., Kress, B. T., Wiltberger, M., Tobiska, W. K., Grajewski, B., and Xu, X.: Atmospheric ionizing radiation from galactic and solar cosmic rays, Current Topics in Ionizing Radiation Re- search, edited by: Mitsuru N., InTech Publisher, ISBN 978-95351-0196-3, 2012.

Mertens, C. J., Meier, M. M., Brown, S., Norman, R. B., and $\mathrm{Xu}, \mathrm{X} .:$ NAIRAS aircraft radiation model development, dose climatology, and initial validation, Space Weather, 11, 603-635, doi:10.1002/swe.20100, 2013.

Mironova, I. A., Aplin, K. L., Arnold, F., Bazilevskaya, G. A., Harrison, R. G., Krivolutsky, A. A., Nicoll, K. A., Rozanov, E. V., Turunen, E., and Usoskin, I. G.: Energetic Particle Influence on the Earth's Atmosphere, Space Sci. Rev., 194, 1-96, 2015.

Müller, R. and Crutzen, P. J.: A possible role of galactic cosmic rays in chlorine activation during polar night, J. Geophys. Res. 98, 20483-20490, 1993.

Nicolet, M.: On the production of nitric oxide by cosmic rays in the mesosphere and stratosphere, Planet. Space Sci., 23, 637-649, 1975.

Norman, R. B., Blattnig, S. R., De Angelis, G., Badavi, F. F., and Norbury, J. W.: Deterministic pion and muon tranport in Earth's atmosphere, Adv. Space Res., 50, 146-155, 2012.

Norman, R. B., Slaba, T. C., and Blattnig, S. R.: An extension of HZETRN for cosmic ray initiated electromagnetic cascades, Adv. Space Res., 51, 2251-2260, 2013.

O'Neill, P. M.: Badhwar-O'Neill 2010 galactic cosmic ray flux model - revised, IEEE T. Nucl. Sci., 57, 3148-3153, 2010.

Picone, J. M., Hedin, A. E., Drob, D. P., and Aikin, A. C.: NRLMSIS-00 empirical model of the atmosphere: Statistical comparisons and scientific issues, J. Geophys. Res., 107, 1468, doi:10.1029/2002JA009430, 2002.

Porter, H. S., Jackman, C. H., and Green, A. E. S.: Efficiencies for production of atomic nitrogen and oxygen by relativistic proton impact in air, J. Chem. Phys., 65, 154-167, 1976.

Rienecker, M. M., Suarez, M. J., Gelaro, R., Todling, R., Bacmeister, J., Liu, E., Bosilovich, G., Schubert, S. D., Takacs, L., Kim, G.-K., Bloom, S., Chen, J., Collins, D., Conaty, A., da Silva, A., Gu, W., Joiner, J., Koster, R. D., Lucchesi, R., Molod, A., Owens, T., Pawson, S., Pegion, P., Redder, C. R., Reichle, R., Robertson, F. R., Ruddick, A. G., Sienkiewicz, M., and Woollen, J.: MERRA: NASA's modern-era retrospective analysis for research and applications, J. Climate, 24, 3624-3648, doi:10.1175/JCLID-11-00015.1, 2011.

Ruderman, M. A. and Chamberlain, J. W.: Origin of the sunspot modulation of ozone: its implications for stratospheric NO injection, Planet. Space Sci., 23, 247-268, 1975.

Sander, S. P., Abbatt, J., Barker, J. R., Burkholder, J. B., Friedl, R. R., Golden, D. M., Huie, R. E., Kolb, C. E., Kurylo, M. J., Moortgat, G. K., Orkin, V. L., and Wine, P. H.: Chemical kinetics and photochemical data for use in atmospheric studies, Evaluation Number 17, JPL Publication 10-6, Pasadena, California, USA, 2011

Semeniuk, K., Fomichev, V. I., McConnell, J. C., Fu, C., Melo, S. M. L., and Usoskin, I. G.: Middle atmosphere response to the solar cycle in irradiance and ionizing particle precipitation, Atmos. Chem. Phys., 11, 5045-5077, doi:10.5194/acp-11-50452011, 2011.

Slaba, T. C., Blattnig, S. R., Reddell, B., Bahadori, A., Norman, R. B., and Badavi, F. F.: Pion and electromagnetic contribution to dose: Comparisons of HZETRN to Monte Carlo results and ISS data, Adv. Space Res., 52, 62-78, 2013. 
Smart, D. F. and Shea, M. A.: Geomagnetic cutoffs: A review for space dosimetry calculations, Adv. Space Res., 14, 1078710796, 1994.

Smart, D. F. and Shea, M. A.: A review of geomagnetic cutoff rigidities for earth-orbiting spacecraft, Adv. Space Res., 36, 20122020, 2005.

Solomon, S., Rusch, D. W., Gerard, J.-C., Reid, G. C., and Crutzen, P. J.: The effect of particle precipitation events on the neutral and ion chemistry of the middle atmosphere, 2, Odd hydrogen, Planet. Space Sci., 29, 885-892, 1981.

Solomon, S., Kinnison, D., Bandoro, J., Garcia, R.: Simulations of polar ozone depletion: an update, J. Geophys. Res., 120, 79587974, doi:10.1002/2015JD023365, 2015.

SPARC: SPARC (Stratosphere-Trospophere Processes and their Role in Climate) Report on the Lifetimes of Stratospheric Ozone-Depleting Substances, Their Replacements, and Related Species, edited by: Ko, M. K. W., Newman, P. A., Reimann, S., and Strahan, S. E., SPARC Report No. 6., WCRP-15/2013, available at: http://www.sparc-climate. org/publications/sparc-reports/sparc-report-no6/, SPARC Office, Zurich, Switzerland, 2013.

Spivakovsky, C. M., Logan, J. A., Montzka, S. A., Balkanski, Y. J., Foreman-Fowler, M., Jones, D. B. A., Horowitz, L. W., Fusco, A. C., Brenninkmeijer, C. A. M., Prather, M. J., Wofsy, S. C., and McElroy, M. B.: Three-dimensional climatological distribution of tropospheric OH: Update and evaluation, J. Geophys. Res., 105, 8931-8980, doi:10.1029/1999JD901006, 2000.

Strahan, S. E., Duncan, B. N., and Hoor, P.: Observationally derived transport diagnostics for the lowermost stratosphere and their application to the GMI chemistry and transport model, Atmos. Chem. Phys., 7, 2435-2445, doi:10.5194/acp-7-2435-2007, 2007.
Strode, S. A., Rodriguez, J. M., Logan, J. A., Cooper, O. R., Witte, J. C., Lamsal, L. N., Damon, M., Van Aartsen, B., Steenrod, S. D., and Strahan, S. E.: Trends and variability in surface ozone over the United States, J. Geophys. Res.-Atmos., 120, 9020-9042, doi:10.1002/2014JD022784, 2015.

Thorne, R. M.: The importance of energetic particle precipitation on the chemical composition of the middle atmosphere, Pure Appl. Geophys., 118, 128-151, 1980.

Usoskin, I. G., Kovaltsov, G. A., and Mironova, I. A.: Cosmic ray induced ionization model CRAC:CRII; An extension to the upper atmosphere, J. Geophys. Res., 115, D10302, doi:10.1029/2009JD013142, 2010.

Vitt, F. M. and Jackman, C. H.: A comparison of sources of odd nitrogen production from 1974 through 1993 in the Earth's middle atmosphere as calculated using a two-dimensional model, J. Geophys. Res., 101, 6729-6739, 1996.

Vitt, F. M., Armstrong, T. P., Cravens, T. E., Dreschhoff, G. A. M., Jackman, C. H., and Laird, C. M.: Computed contributions to odd nitrogen concentrations in the Earth's polar middle atmosphere by energetic charged particles, J. Atmos. Sol.-Terr. Phy., 62, 669683, 2000.

Warneck, P.: Cosmic radiation as a source of odd nitrogen in the stratosphere, J. Geophys. Res., 77, 6589-6591, 1972.

Wegner, T., Kinnison, D. E., Garcia, R. R., and Solomon, S.: Simulation of polar stratospheric clouds in the specified dynamics version of the whole atmosphere community climate model, J. Geophys. Res.-Atmos., 118, 4991-5002, doi:10.1002/jgrd.50415, 2013.

WMO (World Meteorological Organization): Scientific Assessment of Ozone Depletion: 2014, Global Ozone Research and Monitoring Project-Report No. 55, Geneva, Switzerland, 2014. 